\title{
HERBAGE DRY MATTER PRODUCTION: THE BALANCE BETWEEN GROWTH AND DEATH
}

\author{
C!. J. Korte, G. W. Sheath*
}

A gronomy Department, M assey University, Palmerston N orth

\section{Abstract}

Dry matter accumulation patterns in pastures are the net result of two processes: the growth of new herbage and the death, and disappearance of old herbage. The relative importance of these two processes in influencing regrowth is discussed and illustrated with data from two markedly different pasture types. In a Nui ryegrass/ white clover pasture and a pure Maku lotus sward, defoliation intensity and season markedly influence the accumulation of dead material, its subsequent disappearance, and hence net dry matter production. The effect of new growth on dry matter accumulation was greatly diminished by within-canopy dry matter losses. The implications of herbage death and disappearance are discussed with reference' to the adequacy of certain experimental techniques in estimating herbage dry matter production.

\section{INTRODUCTION}

NumERous workers (e.g., Brougham, 1956; Donald and Black, 1958) have highlighted the close relationship between leaf area index, light interception, and pasture growth. As a result, many pasture management systems have been proposed with the objective of maximizing light interception in order to obtain high annual yields (Donald, 1956; Brougham, 1959). However, among many other factors that influence pasture production, dry matter losses. through tissue death and decay are also important determinants of net pasture productivity (Campbell, 1964) . Hunt (1965) and Hunt (1970) have highlighted the importance of these loss processes in restricting dry matter accumulation towards the later stages of regrowth in grass/clover swards. Because of these within-canopy losses there is generally a discrepancy between harvested yield and gross dry matter production and one is seldom an accurate reflection of the other, particularly under lax defoliation (Morris, 1970; Davidson and Birch, 1972; Jackson, 1974).

This paper presents dry matter data that illustrate the relative importance of growth and decay in the net accumulation of dry matter in two markedly different sward types, namely 'Grasslands

*Present address: Ruakura Agricultural Research Centre, Hamilton. 
Nui' ryegrass/'Grasslands Huia' white clover and 'Grasslands Maku' lotus swards. The influence of these two processes in assessing canopy production measurements is highlighted.

\section{EXPERIMENTAL}

The three experiments reported in this paper were conducted at Massey University between 1975 and 1977. In all experiments, data were statistically analysed as a randomized block design with four replicates.

\section{Ryegrass/White Clover experiment}

A grazing experiment was conducted during 1976-7 on a 'Grasslands Nui' perennial ryegrass (Lolium perenne) /'Grasslands Huia' white clover (Trifolium repens) pasture. Two grazing intensities were compared, and these were defined in terms of residual leaf area index (LAI), namely, HARD (LAI $=0-0.2)$ and LAX $(\mathrm{LAI}=0.6-1.0)$. Leaf death during later stages of regrowth was minimized by grazing pastures when the canopy intercepted $95 \%$ of noon sunlight. At the end of each regrowth cycle, plots were grazed with ewes for 2 to 3 days.

In each plot, mean herbage dry matter levels were determined from three randomly placed quadrats $\left(0.18 \mathrm{~m}^{2}\right)$ cut to ground level. These were taken before and after grazing and then at intervals of 3 to 7 days during regrowth. A subsample of cut herbage was dissected into three fractions: live herbage, senescent (yellow or brown) ryegrass stem, and remaining senescent herbage (mainly ryegrass leaf).

Immediately after each grazing, four circular frames $(10.2 \mathrm{~cm}$ diameter) were placed at random in each plot. Within each frame, all live ryegrass reproductive tillers, which consisted of varying amounts of stem and practically no leaf, were tagged with coloured plastic rings. Before the next grazing the turfs inside the frames were removed and the yield of those marked tillers still alive measured. The yield of dead stems was determined from dissection of cut herbage taken from the $0.18 \mathrm{~m}^{2}$ quadrats.

\section{LOTUS EXPERIMENT A}

Between 7.9.76 and 16.5.77, a cutting experiment was conducted on pure swards of 'Grasslands Maku' (Lotus pedunculatus). The treatments during this period were:

A: three cuts down to $1.5 \mathrm{~cm}$ (variable frequency) 
$\mathrm{B}$ : four cuts down to $1.5 \mathrm{~cm}$ (variable frequency)

C: six cuts down to $1.5 \mathrm{~cm}$ (at 6-weekly intervals)

D: six cuts down to $9.5 \mathrm{~cm}$ (at 6-weekly intervals)

E: six cuts down to $9.5 \mathrm{~cm}$ (variable frequency)

Final and residual herbage dry matter levels were assessed by taking ground level quadrat cuts $\left(0.1 \mathrm{~m}^{2}\right)$ before and after each mowing. Herbage dry matter levels during regrowth were similarly determined at approximately 3-weekly intervals. Quadrat cuts were taken from grid positions randomly allocated within a 0.5 $\times 0.5 \mathrm{~m}$ grid pattern. Harvested plant material was subsampled and dissected into, shoots, stubble and dead material. Stubble was classified as living shoot tissue without an intact terminal apex, and it excluded any intact, subtending axillary shoots. No clippings were returned to the plot areas.

\section{LOTUS EXPERIMENT B}

The cutting treatment imposed between 9.9.75 and 18.5.76 involved cutting down to 1.5 (HF) and 9.5 (LF) cm every 3 weeks, and to $1.5(\mathrm{HI})$ and $9.5(\mathrm{LI}) \mathrm{cm}$ every 6 weeks. For each cut, mown dry matter yields were determined and residual dry matters were assessed by taking ground level quadrat cuts $\left(0.1 \mathrm{~m}^{2}\right)$ in each plot.

\section{RESULTS}

In all three experiments net herbage dry matter production was considered as the cumulative difference between residual and final dry matter levels of individual regrowth cycles.

\section{Ryegrass/White ClOVER EXPERIMENT}

The patterns of dry matter accumulation following hard and lax grazing during late spring/summer are shown in Fig. 1. The dead component of the pasture, representing senescent leaf and ryegrass stem, continued to accumulate throughout the period of measurement where lax grazing occurred. Relatively little dead material was present in hard-grazed pasture. Average net accumulation rates for this period are presented in Table 1. Although there was no difference between total net herbage growth rates of the two treatments, the average rate of "live" herbage accumulation was markedly greater with hard grazing. The difference between these two measurements was due to the significantly 


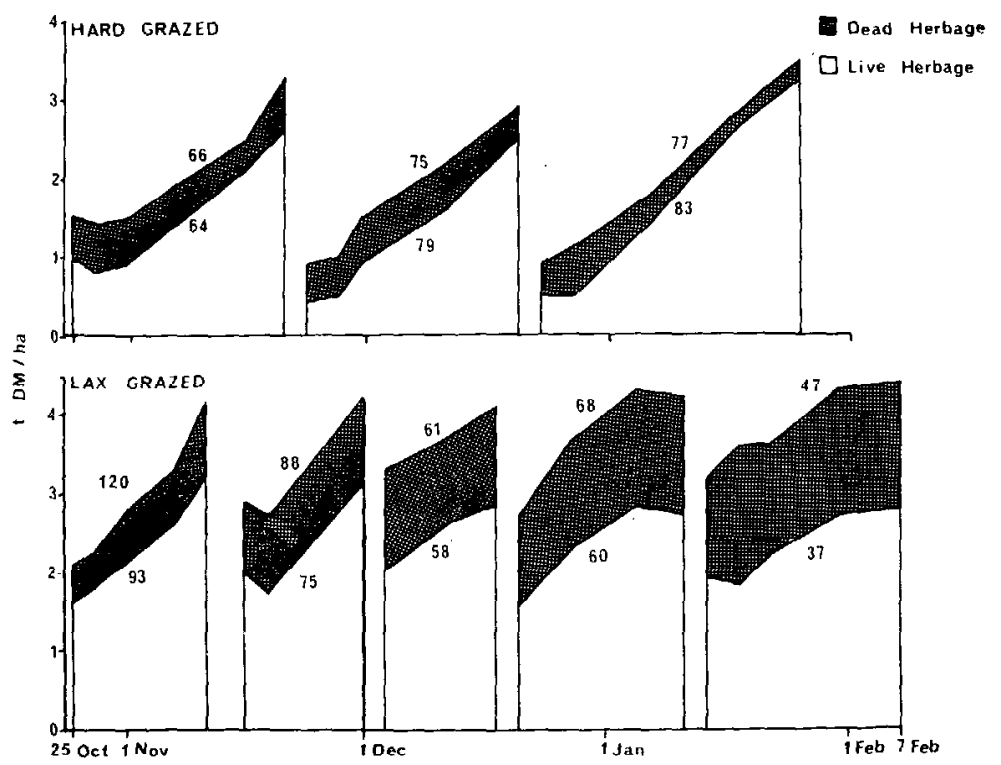

FIG. 1: Live and dead dry matter levels during spring/summer in the ryegrass/white clover experiment. Average net accumulation rates ( $k g$ DM/ halday) of live herbage and total herbage for each regrowth cycle are shown below and above hatching, respectively.

TABLE 1: AVERAGE NET ACCUMULATION RATES IN THE RYE. GRASS/WHITE CLOVER EXPERIMENT FROM 1 OCTOBER 1976 TO MID-FEBRUARY 1977 (kg DM/ha/day)

\begin{tabular}{lccc}
\hline & Lax & Hard & L.S.D. (5\%) \\
\hline Dead herbage & & & \\
Leaf and sheath & 8.6 & -1.4 & 9.7 \\
Ryegrass stem & 3.8 & -1.4 & 4.1 \\
Total & 12.4 & -2.8 & 12.7 \\
Live herbage & 61.9 & 75.8 & 12.8 \\
Total herbagc & 74.3 & 73.0 & n.s. \\
\hline
\end{tabular}

greater accumulation of dead material with lax grazing. In this treatment the net accumulation of dead material between October and mid-February represented $1.3 \mathrm{t} \mathrm{DM} /$ ha, of which $70 \%$ was leaf and sheath and the remainder was dead ryegrass stem.

Dry matter changes of tagged ryegrass stems for one regrowth cycle during late spring are presented in Table 2 . These data illustrate how measurement of net accumulation of dead herbage 
TABLE 2: DRY MATTER CHANGES OF MARKED RESIDUAL RYE. GRASS STEMS FOR A LAX (3.12.76-17.12.76) AND A HARD (24.11.76. 20.12.76) REGROWTH CYCLE ( $\mathrm{kg} \mathrm{DM} / \mathrm{ha})$

\begin{tabular}{|c|c|c|}
\hline & Lax & $\mathrm{H}$ ard \\
\hline \multicolumn{3}{|l|}{ Dry matter of marked stems } \\
\hline Start of regrowth & $869 \pm 59$ & $82 \pm 19$ \\
\hline End of regrowth & $422 \pm \mathrm{a} 4$ & $29 \pm 22$ \\
\hline Change during regrowth & $-427(33)^{a}$ & $-53(2)$ \\
\hline Net change in total dead stem & -8 & -2 \\
\hline
\end{tabular}

a Rate of dry matter loss ( $\mathrm{kg} \mathrm{DM} / \mathrm{ha} /$ day)

reflects only part of the process occurring. After lax grazing there was a considerable weight loss from grazed ryegrass stems that were marked at the start of regrowth. However, even at a rate of $33 \mathrm{~kg} / \mathrm{ha} /$ day, this loss was not reflected in a similar change in dead stem. A similar pattern occurred after hard grazing, although the loss was much smaller.

Data in Fig. 2 illustrate another aspect of the balance between herbage growth and disappearance. Dead material which accumulated in spring disappeared from the sward during autumn. Thus, despite "live" herbage accumulating at $33 \mathrm{~kg} / \mathrm{DM} / \mathrm{ha} / \mathrm{day}$, the net herbage growth rate was only $7 \mathrm{~kg} \mathrm{DM} / \mathrm{ha} /$ day.

\section{LOTUS EXPERIMENT A}

Net shoot production was considered as the cumulative difference between residual and final dry matter levels of the total shoot pool, and this was highest where $9.5 \mathrm{~cm}$ cutting occurred

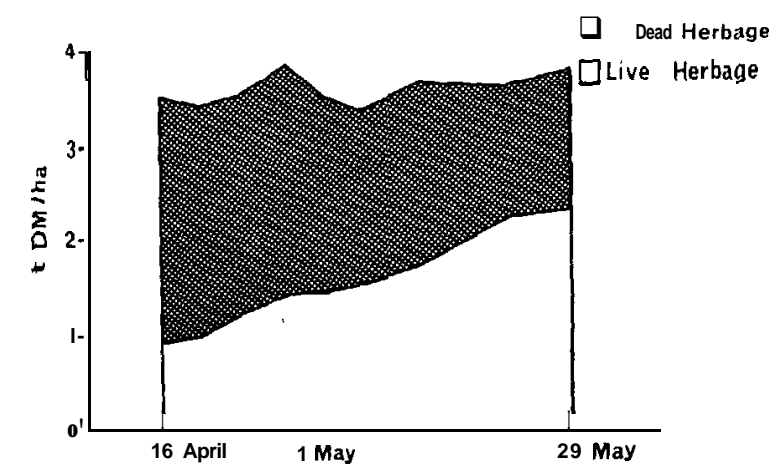

FIg. 2: Dry matfer changes during an autumn regrowth cycle in a rye. grass/white cl over sward. 
TABLE 3: NET SHOOT AND NET HERBAGE PRODUCTION IN LOTUS EXPERIMENT A (kg DM/ha)

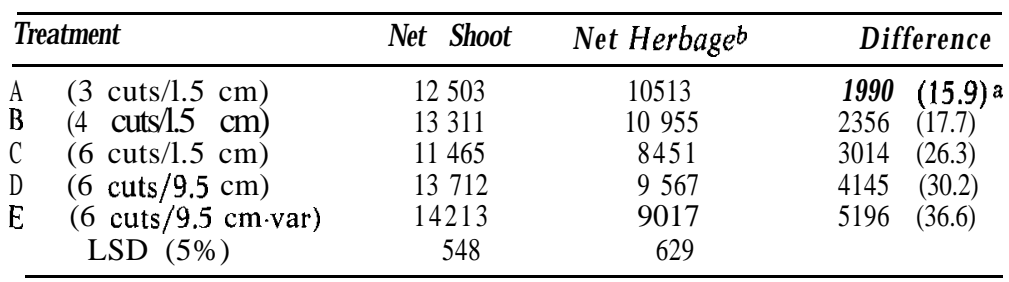

a Losses expressed as a percentage of total net shoot production,

b Net herbage represents live shoots, stubble and dead matter.

(treatments D and E, Table 3). However, it was in these same treatments that within-canopy losses were greatest, and as a result it was the infrequent, severely defoliated treatments (A and B) that had the highest net herbage production (includes live shoots, stubble, and dead matter). The difference between net shoot and net herbage production in this experiment can be considered as representing those losses that were incurred through the death and disappearance of stubble tissue and dead material, As cutting became more frequent at the $1.5 \mathrm{~cm}$ cutting height, the stubble component increased and dry matter losses were greater. In treatment

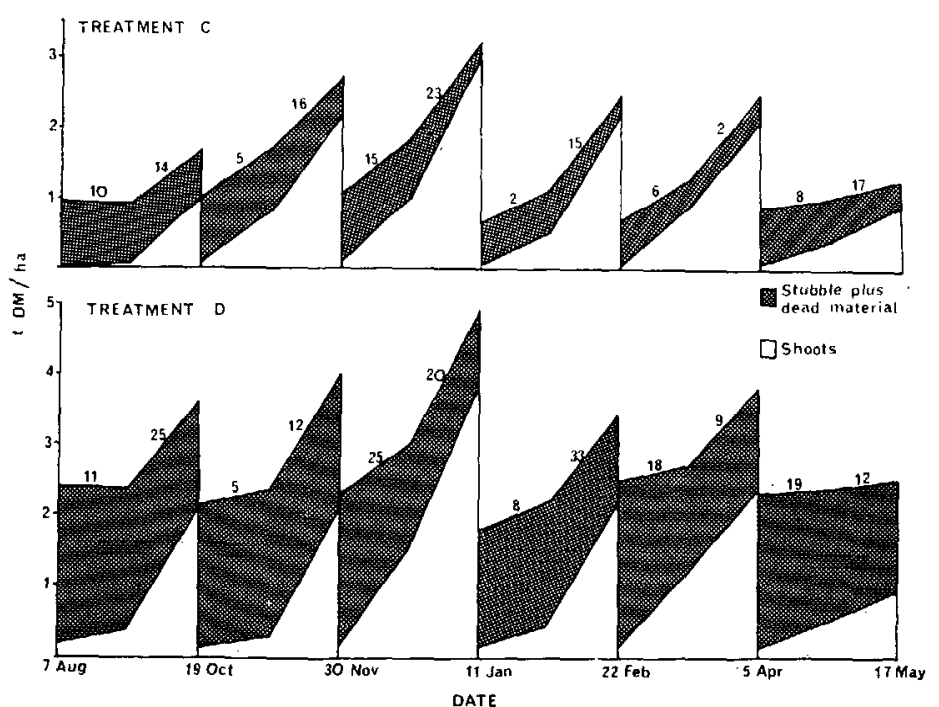

FIG. 3: Shoot and stubble + dead matter yields in treatments $C$ and $D$ of Lotus Experiment A. Figures above the histogram are average daily loss from the stubble and dead component (kg DM/ha/day). 
C, approximately $3.0 \mathrm{t} \mathrm{DM} / \mathrm{ha}$ was lost during the experimental period, and where higher cutting occurred the losses were even more marked. Approximately 5.0 t DM/ha was lost in treatment E. Not only did these within-canopy losses reduce net herbage production, but, depending on which parameter was considered, they also altered the relative production ranking of the various treatments.

The influence that these dry matter losses had within individual regrowth cycles is illustrated in Fig. 3, where shoot and stubble plus dead matter data are presented for treatments $C$ and D. At each cut the dry weight of stubble increased, but, because this component died and dead matter disappeared, the stubble plus dead matter pool declined as regrowth proceeded. These dry matter levels and losses were greater in the laxly cut treatment (D in Fig. 3). It was apparent that, because of these losses, little or no positive net accumulation of dry matter was recorded during early regrowth even though positive shoot growth was occurring.

\section{LOTUS EXPERTMENT B}

In this experiment, net herbage production was considered in two different ways (Table 4). Method A was similar to that in the other experiments and considered net herbage production as the cumulative difference between residual and firial dry matter levels of individual regrowth cycles. In contrast, method B considered it

TABLE 4: NET HERBAGE PRODUCTION IN EXPERIMENT B (kg DM/ha)

\begin{tabular}{|c|c|c|c|c|c|c|c|}
\hline & & Spring & Summer & \multicolumn{2}{|r|}{ Autumn } & \multicolumn{2}{|r|}{ Total } \\
\hline Treatment & \multicolumn{5}{|c|}{ Method A } & & \\
\hline H F & & 1423 & 2281 & & 554 & & 4528 \\
\hline $\mathrm{LF}$ & & 1750 & 2109 & & 550 & & 4409 \\
\hline $\mathrm{HI}$ & & 2140 & 3383 & & 943 & & 5466 \\
\hline LI & & 2586 & 3147 & & 730 & & 6463 \\
\hline $\operatorname{LSD}(5 \%)$ & & 181 & 187 & & 105 & & 220 \\
\hline Treatment & & & Method B & & & & \\
\hline $\mathrm{HF}$ & 1722 & $(+299)^{b}$ & $2293(+12)$ & 526 & $(-38)$ & 4501 & $(+27 \overline{5})$ \\
\hline $\mathrm{LF}$ & 2057 & $(+307)$ & $1654(-455)$ & 12 & $(-538)$ & 3723 & $(-686)$ \\
\hline HI & 2685 & $(+545)$ & $3465(+82)$ & 631 & $(-312)$ & 6781 & $(+315)$ \\
\hline LI & 3121 & $(+535)$ & $2430 \quad(-717)$ & 38 & $(-692)$ & 5589 & $(-874)$ \\
\hline $\operatorname{LSD}(5 \%)$ & 210 & & 212 & 23 & & 217 & \\
\hline
\end{tabular}

b Net production difference between method B-A. 
as the cumulative difference between pre- and post-cut dry matter levels - i.e., mown yields.

Method B did not take into account dry matter change; below mower height, yet it was in this region that stubble died and dead material disappeared. Thus, as residual dry matter decreased during spring, method $\mathrm{B}$ or mown yield overestimated net herbage production. Conversely, as dry matter accumulated below mower height in autumn, method B underestimated net herbage production relative to method A. Similar effects were also apparent where lax defoliation allowed stubble and dead material to accumulate, and net herbage production was again underestimated with mown dry matter yields. This was most apparent when dry matter production for the whole experimental period was considered. Because of these dry matter changes below cutting height the relative production ranking of treatments again altered depending on the method used in assessing net herbage production.

\section{DISCUSSION}

Grazed reproductive ryegrass stems have little capacity for continued expansion and their disappearance rate after lax defoliation in late spring/summer can represent dry matter losses of approximately $30 \mathrm{~kg} \mathrm{DM} / \mathrm{ha} /$ day (Table 2). In the ryegrass/ white clover experiment, the death of ungrazed, mature leaves during the later stages of regrowth was minimized by grazing at 95\% light interception (Hunt, 1965; Tainton, 1974). Thus, the dead material which accumulated came principally from the death of defoliated residual herbage, a process generally ignored or regarded as unimportant during early regrowth. Although residual stubble in ryegrass/white clover pastures is generally regarded as being capable of continued expansion, $70 \%$ of dead material which accumulated in laxly grazed ryegrass/white clover swards was residual leaf lamina and grass sheath.

With the removal of the terminal apex, a defoliated lotus shoot has, in itself, little capacity for further expansion. As stlivile, it can support stubble shoot growth, supply growth substrates from assimilatory and remobilization processes, and eventually die, thereby entering into the dead matter pool. It is this last process, in association with the disappearance of dead material, that can lead to large dry matter losses within regrowing lotus swards. Such losses were commonly in the range of 15 to $20 \mathrm{~kg}$ $\mathrm{DM} /$ ha/day and accounted for up to a third of net shoot growth. 
After defoliation of both sward types, total above-ground dry matter accumulated at a slower rate than that of new herbage, namely, "live herbage" in the grass/clover sward and "new shoots" in the lotus sward. This discrepancy was related to the death and subsequent disappearance of residual tissue. Dry matter production is a basic index used for the evaluation of agronomic practices in pastoral research, but as it does not differentiate between live and dead dry matter, the method of measurement can influence treatment ranking. In lotus Experiment $\mathrm{A}$, it was apparent that within-canopy dry matter losses not only limited net herbage production but also nullified treatment responses that were evident in net shoot production. As a result, the relative ranking of treatments differed in terms of the two productivity measurements.

Because production estimates derived from mower clippings do not take into account changes in the amount of live or dead herbage below mower height, they do not necessarily reflect relative differences in net herbage production above ground (Table 4). Dry matter changes below mower height may result from seasonal changes (Fig. 2), varied defoliation severities, or changing plant habits. Where above-ground net herbage production is required to compare treatments, mower clippings will give an unreliable estimate if any of these changes below mower height can occur.

In evaluating plant responses to agronomic practices, gross production (new growth, including losses of this material during regrowth) is an important measurement, yet it is rarely considered because of difficulty in measurement. With lotus, new shoots could be identified because of the plant's growth form, and as the loss of new leaves was minimal during regrowth, net shoot production can be considered to approximately represent gross production. The competitive potential of a lotus canopy was therefore more closely associated with gross production than with net production. Similarly, factors such as root growth or responses to applied nutrients or water may be considered as being more appropriately related to gross rather than net herbage production. Net herbage productivity may partly reflect gross production or new herbage growth, but it is also influenced by the experimental procedures used in harvesting herbage and/or the degree of utilization attained.

However, in considering "harvested" or "harvestable" production of a system, gross production is not relevant (Campbell, 1964). Net herbage dry matter yield is often used for this purpose, yet even this measurement may be misleading. Where 